Research, part of a Special Feature on Implementing Participatory Water Management: Recent Advances in Theory, Practice and Evaluation

\title{
Re-connecting with a Recovering River through Imaginative Engagement
}

\author{
$\underline{\text { Paul Selman }}^{1}, \underline{\text { Claudia Carter }}^{2}, \underline{\text { Anna Lawrence }}^{2}$, and Clare Morgan $^{3}$
}

\begin{abstract}
Imaginative engagement as a mode of citizen participation - the use of arts-based methods to involve people actively in shared learning experiences-holds promise as a means to increase awareness and understanding, and to build capacity, for sustainable use and management of rivers. We conducted a series of creative writing workshops in a former industrial area of northern England that were focused on a "recovering" river. Participants in the workshops found the process a positive experience and reported changes in their knowledge, attitudes, and actions about the use and management of river environments locally and more generally. The "catchment consciousness" of members appeared to increase, and their raised levels of interest led them to invest time in researching the history and geography of the river. We conclude that the method has significant potential for complementing collaborative approaches to river planning and management.
\end{abstract}

Key Words: imaginative engagement, participatory methods, river management, social learning, water catchment consciousness

\section{INTRODUCTION}

Many rivers have been intensely modified and often degraded as a result of urban growth, flood control, and industrial development. Whereas the river would once have been the social and economic focus of an area, and communities would have accustomed themselves to its vagaries, in many urbanized areas it has now virtually been forgotten. Yet rivers provide critical ecosystem services (Zedler and Kercher 2005, Bohensky et al. 2006) and can be a focus for people's pride in place and for the identity of an area (Pedroli 2005), especially where stakeholders are engaged in processes of river restoration.

Since the mid-1970s, EU Directives have required action on river quality (Kaika 2003). Especially since the EU Water Framework Directive of 2000 (Commission of the European Communities 2000), the initial focus on water chemistry has evolved into a broader concern for community participation (White and Howe 2003). The organizations responsible for river management increasingly show a strong concern for social inclusion, as disadvantaged sections of society are disproportionately affected by water pollution and flooding and yet are often relatively unheard in the decision-making process (Wilkinson 2005). Recent exceptional floods in Europe have been related to a range of factors including climate change, river engineering, floodplain development, rural land conversion, and efficient modern agricultural land drainage (EEA 2005, Marsh and Hannaford 2007). This has resulted, amongst other things, in policy pressure to curb development in low-lying areas and to promote "soft engineering" solutions to flood management (e.g., Adams et al. 2004, Moss and Monstadt 2008).

This paper reflects on the experience of involving communities in dialogues about choices concerning river catchments through a participatory approach known as imaginative engagement. The catchment is a high order system, and lay people may lack interest in or comprehension of the abstract, complex, strategic, and long-term concepts associated with river basin plans. Also, stakeholders may need considerable help to imagine what a future river system would look like, as the modern watercourse is often a residual vestige of a forgotten landscape. Furthermore, local communities may have experienced severe floods and are looking for 
reliable and tested options to reduce the risk of flooding; hence they may less readily be convinced by "soft" than "hard" engineering solutions.

Our research thus centered on enabling participants to consider large-scale processes and take long-term perspectives, whilst imagining how their river might once again be valued, cared for, and used rather than forgotten or disparaged. We experimented with an approach based on techniques of imaginative engagement, in the expectation that this would help people grasp important functions and meanings and identify with possible future catchment management options. These methods use the arts to communicate and help people engage with complex and sometimes abstract issues, by providing icons and metaphors, and by giving space to the imagination and emotions. In this instance, we were curious to know whether the methods could help rekindle a lost capacity to sense the ways in which rivers work -people's alleged "catchment consciousness" (Wilkinson 2005).

\section{LITERATURE REVIEW}

The EU Water Framework Directive (Commission of the European Communities 2000) has created an important new context for seeking communities' views and knowledge in relation to river basin planning. Despite a long period of settlements "turning their backs" on rivers and becoming disconnected from their watersheds (Stokman 2008), people still associate them with a range of positive and negative values (Dalrymple 2006). Murray and Myant (2006), for example, propose that the interests of the public typically tend to be local whilst those of professional stakeholders tend to be system-wide.

A variety of official and unofficial guidance has been produced on integrated river management in the United Kingdom (e.g., Department of Environment, Food and Rural Affairs 2006), and numerous initiatives exist including river trusts, catchment sensitive farming, catchment flood management plans, and river basin planning with its associated Liaison Panels (see Piper 2005). In addition, several projects have provided recent UK/ EU evidence of participatory river basin management, such as URBEM (Newcastle City Council 2005), Mersey Valley Initiative (Kidd and Shaw 2000, Tippett 2005), and Cycleau (Devon Wildlife Trust 2005). There has also been wider
European experience of grassroots leadership of water and environmental management, for instance in relation to farming practices (Blomqvist 2004) and multi-stakeholder river contracts (Rossillon 2004).

Effective community engagement in river basin futures has often failed to secure social outcomes either because involvement has been restricted to a small circle of influential stakeholder groups (Junker et al. 2007), or because of institutional barriers (Moss 2004, Wilkinson 2005), or because decision-makers presume a "deficit model" of public knowledge (Eden 1998, Eden and Tunstall 2006) and thus over-rely on the communication of scientific information. Conversely, there is scope to base approaches on collaboration (Orr et al. 2007) and social learning (Steyaert and Ollivier 2007).

One of the key challenges of river basin planning is that rivers have often been modified so extensively over a period of decades or even centuries, that communities have effectively become "disconnected" from them. Re-imagining rivers may thus entail going beyond participation into a deeper process of social learning (Blackmore et al. 2007, Petts 2007), which can set episodic plan production within more continuous practices that engage with sustainable living (Collins et al. 2005, Pedler et al. 2006). This can potentially lead to new knowledge, acquisition of technical and social skills, development of trust and relationships, negotiation, and collective action (Muro and Jeffrey 2008, Walker et al. 2006). Social learning is a term with diverse applications, but in the context of this paper refers to the changes in knowledge, understanding, and behavior that arise through social processes of sharing experiences and perspectives, and of reflecting and learning collaboratively. For example, the Social Learning in Integrated Management (SLIM) project evaluated the development and deployment of knowledge for transformative actions at socially and ecologically meaningful scales within river basins using systems thinking and systemic co-researching (Collins et al. 2007, Ison and Watson 2007). PahlWostl (2006) and Pahl-Wostl et al. (2007) reported on the connections between social learning and collaborative governance in relation to changing paradigms for floodplain management in The Netherlands.

There is specific and relatively unexplored scope for using methods of imaginative engagement based on creative arts as a way of achieving social learning 
and understanding complex sustainability problems (Chartered Institution of Water and Environmental Management 2009, Kemp and Griffiths 1999). Whilst many imaginative engagement exercises employ visual practices (e.g., Morris and Cant 2004), some have utilized storytelling and creative writing (Simm and Samuels 2006, Seeley Brown et al. 2005). Stories are particularly pertinent in relation to "sense making" (putting forward tentative and plausible explanations to a problem especially in situations of uncertainty and ambiguity) and nurturing communities of practice through narration, collaboration, and social construction. In the context of the SLIM project, researchers showed how discourses around social learning enabled participants to interpret and cohere fragmented information (Blackmore 2007, Steyaert and Jiggins 2007). Gull et al. (2002) used creative writing as a tool in medical education, and found that, despite some problems of sustaining participants' commitment, there was a tendency for self-reflective multidisciplinary learning and a level playing field between the different professions.

Thus, despite extensive experience of applying diverse participatory methods to river restoration, few exercises have enabled the public and professionals to spend time sharing stories, local wisdom, hopes, and fears in a personally engaged manner. Where this occasionally has happened, through arts-based projects, the results have rarely been critically documented. Our research thus innovated by enabling a group to work closely together in an equal, creative, and enjoyable manner over an extended period, in order to explore the engagement, discovery, social learning, commitment, and imagining that occurred.

\section{APPROACH AND METHODS}

\section{Creative writing as a tool of imaginative engagement}

As noted above, imaginative engagement can draw on a wide repertoire of methods from the visual to the literary. Mainly in view of the expertise available to us, and in the light of previous positive experience of its use (Sampson 2004), we chose an approach based on creative writing. Key characteristics of imaginative engagement approaches are that they are highly personal but with the potential to be shared collectively; are exploratory; involve using personal experience to gain a deeper understanding of ourselves and what is around us; are able to help us attach meaning and see different perspectives; and are a means of emotional connection with past and present experiences and our environment. They also provide settings in which relevant scientific information can be sought and applied in reflexive ways.

We were particularly interested in answering three research questions:

- Can methods of imaginative engagement raise catchment consciousness?

- Are these methods likely to lead to identifiable changes in values, knowledge, and personal action?

- Are there indications that imaginative engagement can raise social and institutional capacity for contributing to the sustainable development of river basins?

These were ambitious questions which we were aware could not be fully answered within the time and budget constraints of one exercise, though we did aspire to achieve significant insights. Broadly, we were interested in finding out whether imaginative engagement would help move beyond participation, to social learning and change, as a way of sharing and raising awareness, knowledge, and skills, in relation to conceptually complex issues which need to be vividly imagined for breakthroughs to occur.

\section{Case study area}

Our project was set within a postindustrial area of South Yorkshire, United Kingdom. The location was a $20-\mathrm{km}$ stretch of the valley of the River Dearne, an area which had been at the heart of the United Kingdom's coal mining and steelmaking industries before these declined catastrophically during the 1980s (Ling et al. 2007). The former industrial land is now largely reclaimed and affords an unexceptional landscape of distributor roads, "big shed" commercial and retail parks, and volume housing, though it also includes some interesting provision for wildlife and recreation. In addition to economic and social hardship, communities have suffered periodic flooding, most notably in the summer of 2007 when extensive damage and disruption occurred. Although the River Dearne is 
substantially less polluted than it was 30 years ago, it is still a highly modified and obscured feature, yet with substantial scope for further restoration and for contributing to the area's changing identity. Our project specifically related to a recent initiative called Dearne Valley Green Heart which addresses a program of regeneration and is led by the Environment Agency (the organization responsible, inter alia, for river basin planning and management).

\section{Project team and recruitment of participants}

Our research team comprised a creative writing expert, two social researchers with experience in participatory processes and project evaluation, a landscape planner, and an environmental scientist. We commenced with a stakeholder workshop organized at an NGO nature reserve central to the Dearne Valley. This area of constructed wetlands on the site of former heavy industry has become a popular local venue and provided neutral territory for a communication and developmental event. In the absence of a sampling frame for local stakeholders we used a snowball approach (socalled because of the analogy of a snowball growing as it rolls downhill) whereby research access to the field of study is secured through the help and influence of participants and their contacts (Scott and Marshall 2005, Measham 2006). We approached 25 stakeholders and recruited 13 attendees drawn from local government, government agencies, NGOs, research groups, and the local community. The workshop ran as a series of plenaries and small group discussion to raise awareness, identify key local issues and information sources, and generate leads on recruiting and running a writing group.

Following this event, we recruited participants by advertising in local centers and libraries; contacting voluntary organizations and parish councils; and using community websites, word of mouth, and a local newspaper article. Enquirers were advised of the purpose of the exercise, and the requirement to commit to a series of early evening sessions. Having recruited a viable and reasonably diverse group (see Table 1) we conducted six 2-hour workshops, and also arranged additional masterclass tutorials, at the request of the participants, in the meeting room of a small local museum. The research concluded with an event that combined research dissemination with a celebration of the anthology produced by the writers. Reflecting the "center stage" role of the participants, we held this in a relatively informal setting in a centrally located parish hall, and invited family and friends of the participants as well as professional stakeholders.

Although we invested considerable time and effort in recruitment, the number of participants recruited (11) and those who were able to participate in three or more workshops (7) were at the lower end of our target. A minority of the group had qualifications relevant to environmental science, so there was scope to blend "lay" and "expert" knowledge (see Table 1). This size of group is not untypical of indepth qualitative research projects where the information gained from each participant is seen as a valid contribution to the state of knowledge (see Jönsson and Gustavsson 2002, and Cloutier-Fisher 2005, Hahn et al. 2006). We asked much of our group in terms of writing and feedback, and so participation had to be "interest driven". Although we had three dropouts, these were probably no more than for a comparable evening class; it was, however, unfortunate that this included the loss of two professionals in their 20s (an age group consequently lost from the project sample) because of unexpected evening commitments at work arising shortly after joining the group.

\section{Creative writing workshops}

The workshops were led by an expert in creative writing, who spent considerable time familiarizing herself with the area beforehand. Practical investigation of the Dearne Valley from source to confluence was augmented by library research and discussions with an amateur local historian. As well as having a research function, it was important (from a research ethics perspective) that participants would reap rewards from their significant input of time and effort by developing their own skills and self-confidence. Whilst each workshop had a clear purpose and pattern, organization was flexible and responsive to participants' interests, experience of writing, and knowledge levels. Facilitation deliberately left room for movement in subject and treatment within the overall context of catchment consciousness.

The writing sessions thus developed and enabled individual creative interpretations of the Dearne catchment area-its characters, its society, its values, its physical/geographical disposition, where 
Table 1. Summary of project participants sample $(\mathrm{N}=7)$.

\begin{tabular}{|c|c|c|c|c|c|c|c|}
\hline \multicolumn{2}{|l|}{ By gender } & \multicolumn{2}{|l|}{ By age } & \multicolumn{2}{|l|}{ By occupation } & \multicolumn{2}{|c|}{ Knowledge } \\
\hline Male: & 3 & 18-30: & 0 & Part-time work: & 1 & Expert: & 2 \\
\hline \multirow[t]{2}{*}{ Female: } & 4 & 31-60: & 4 & Full-time work: & 3 & Lay: & 5 \\
\hline & & 61-80: & 3 & Perman. retired: & 3 & & \\
\hline
\end{tabular}

the area "comes from" and where it is "going", and the issues that face it. As creative writing requires context and inspiration, participants were asked to bring in visual images, objects, music/sounds, "found" items, pieces of writing they had read, or any other means through which they wished to engage with the Valley and with rivers more generally. Overall, the pedagogic method was one of guided and participative feedback, complemented by the production, where desired, of a reflective journal in which general observations of anything the participants felt relevant could be recorded during and between meetings.

\section{Evaluating the writing workshops}

We monitored and evaluated the project through a process we termed embedded evaluation, to understand how participants engaged with the process and changed through and beyond the course of the workshops. Whereas evaluation of participation may occur as perhaps a single event around the end of a project, we embedded our monitoring and evaluation in the workshops so that the range of effects could be assessed and reflected upon throughout. This process utilized a range of conventional evaluation methods, namely (1) audio-recording of each workshop; (2) participant observation during workshops; (3) workshop evaluation forms completed after each workshop; (4) one-to-one semi-structured interviews half-way through the workshop series; (5) a river/project journal that each participant was given and encouraged to use; (6) questionnaires at the start and end of the sessions, and three months after. The questionnaires were designed to exceed the usual data collated for participation exercises (e.g., who participated, what was contributed) to gauge the lifestyle, behavior, and perceptions of participants and their general environmental and rivermanagement-specific knowledge, and how these changed (or not) over time. The outputs from each workshop session also provided evidence of changing perceptions and knowledge, as well as contributing to an edited anthology.

\section{RESULTS}

\section{The effects of imaginative engagement on participants}

Our various evaluation techniques indicated that using imaginative writing as a tool for active engagement and learning was a positive and valued experience for all. Each participant stated at least once that it was interesting and important to hear, and realize the existence of, the different views and associations that each person has concerning rivers and the environment more generally.

Responses indicate variable effects on participants' behaviors, but a more consistent effect on emotional, physical, and cognitive engagement with rivers, with all participants noting some change to their attitudes and/or thinking. In terms of awareness and knowledge, participants were asked to express their level of agreement/disagreement with nine statements. Five participants agreed moderately or highly with the statement "I discovered some general things" and particularly that they had "acquired a better understanding of the different functions of rivers and how people use and affect them". Most disagreed with the suggestion that understanding rivers was complicated and puzzling, 
indicating that the workshops had enabled information to be assimilated in comprehensible ways.

\section{Signs of "catchment consciousness"}

Some exercises undertaken by the group were intended to reveal the participants' background awareness and to incorporate their findings about the area's history and geography. For example, one exercise, based on an imaginary encounter on the riverbank, illustrated a considerable level of prior awareness of the river and its features:

As we walk along the embankment, we reach the confluence of the Dove with the more languid river Dearne at a point where the Dearne sharply bends to the right, as we view it arriving south from Darfield village. A passing angler says "How Do" as he wends his way home complete with landing net and fishing basket. Obviously fishing is allowed on this stretch of the river.

Another exercise asked people to draw upon their imagination to reflect the time-depth of the catchment, as something which had been there through many generations:

I climbed a small bund to reveal the marshlands and floodplains that lay before me. ... In the distance I could see the chimney of an old mill of some type, surrounded by ancient trees, and the faintness of Hoober Stand at Wentworth, built as a lookout tower in the Jacobite Rebellion. Maybe Bonnie Prince Charlie had looked out from there and seen the floodplains and Darfield as a far different place to what it is now.

A more recent historical reflection shows awareness about the planning process involved in regenerating the area:

Walking to Broomhill with my father from Bolton-upon-Dearne along Ingsfield Lane, we have an uninterrupted view south from the high ground down to the wetlands through which the River Dearne meanders. The pits of Wath Main and Manvers Main loom beyond. ... The years have passed by and it is now 2008. . . . The wetlands from
Broomhill to Bolton-upon-Dearne once used by ice skaters in the winter are no more. Covered by spoil heaps from the pits after the war, the spoil has been landscaped in recent years. The old man in Broomhill is long since dead but the river is revived, pristine again and full of fish.

On another occasion, participants walked along the riverbank and were asked to reflect their thoughts through four "keywords" and explain their selection. This indicated a wide palette of concepts, from very detailed to strategic, for instance:

Catchment - as we came out onto the path and I walked up to the brow of the small hill, I was mindful of the massive catchment area of the Dearne and the Dearne valley here.

Tranquil - peaceful riverside aura, birdsong.

Scummy - edge of river scummy, reminds me where we are, what is near and what ends up in the river.

Slipping - As I walked back up toward the village, I had the feeling that the old village houses were rock solid perched on the top of the hill, and the new and newer and newer-than-that houses were metaphorically slipping in towards the water in the valley...

Writers were regularly asked to write in poetic form, and this seemed particularly useful in enabling them to express the "living" river as a vibrant socialecological system:

Water rushing, dashing, downstream Meets another from the left

This one babbles, smiles and gushes... Fishes gather in the eddies waiting

For the angler's lure...

\section{Emerging themes and insights gained}

The writers engaged with a wide range of materials, many of which they had sourced themselves. One exercise entailed familiarizing themselves with the official report (Pitt 2008) into the floods of June 2007, and then imagining they were people who had been affected locally. The following contribution drew upon official documents, as well as news coverage and accounts from friends: 
Today I read the Pitt Report. He seems compassionate to my needs and what's required to be done. That's all well and good, I'm sure he read my letter from the top to the bottom. Not. He wants to tryliving in this hell of a space for twelve months, well not quite, eleven months, twenty three days and seven hours, not that I'm counting. I haven't had a bath in over twelve months and the shower only two foot by two foot, I stink. How bad is that? . . . My own picturesque home, next to the lovely river. Not now though. Behold, a dirty, damp despairing shell, that's not even half habitable.

One strong factor which emerged was the importance of the river as a recreational focus in former times:

My favourite (tale) was the one about some young lads building a raft in the school summer holidays.. . they pushed themselves off from one bank and got grounded in the middle of the river... for hours as they were too scared to either wade across or shout for help!

Another exercise involved a narrative about a journey within the catchment area (which the writers had to research), revealing significant awareness of the reaches of river beyond their local section:

Here we left the Dearne. David said that he thought it rose somewhere to our left, and he wanted to show me some real hills, so we carried on, passing through a stone mill town, then up a much steeper rise towards a tall mast on top of a mountain. . . . Somewhere down there, in the hills below, the little Dearne started its journey. The journey took it across much of the scene below me, winding among the lumpy folds, through towns that I could not pick out in the faint haze. Though I could not see it, I imagined the distant North Sea . . .

The diversity of writing exercises appears to have enabled vivid expression of multiple aspects of the regenerating river. Both "expert" and "lay" participants fully and equally entered into the writing exercises in ways that stimulated discovery and sharing.

\section{DISCUSSION}

Our key concern was to explore whether imaginative engagement can help people move beyond participation to social learning and adaptive outcomes - in other words, to change their knowledge and practices in relation to rivers and wider environmental concerns.

Our embedded monitoring and evaluation indicate the promising potential of imaginative engagement in this regard. The explorations of people's feelings and imaginations around rivers not only gave them insight into their own and other people's feelings, knowledge, and personalities, but in several cases triggered a change in their own perceptions, thinking, and experiences. For example, one participant at mid-project noted that while she was overall still doing the same as before, she found that she now appreciates her surroundings more and also evaluates decisions more. One participant made similar observations, saying that he now pays more attention to his surroundings and that he is "more interested in rivers and the role they play in society" and has become "more interested in local environmental issues"; another participant reported becoming "more aware of opportunities for participation in my local area" and joining a local environmental group. Several participants also noted that they had started to write much more, so the project was also stimulating changes relating to the project's medium of engagement.

Our research objectives related particularly to the role of imaginative engagement in relation to raising catchment consciousness; stimulating changes in values, knowledge, and personal action; and raising capacity to contribute to the sustainable development of river basins. Catchment consciousness became evident during various exercises, such as those which involved understanding cause and effect in changes to the river's status and condition, and its journey from source to confluence. These exercises were supplemented by the leader's thought-provoking visual presentations with which she introduced and interspersed the workshops. It also seemed that participants with scientific and non-scientific backgrounds enriched their understanding of "catchment" - the former gaining a sense of the memories and journeys that were "caught up" in the river's compass, and the latter developing a stronger appreciation of the river's physical geography and ecology. Sometimes, intense information gathering occurred in fulfilling homework tasks, for example 
through local archives, internet searches, conversations with friends and relatives, and old maps and photographs. For many, a major source of knowledge and insight was other members of the group, both during and outside the workshop sessions. Significantly, the older members reported that, despite enjoying the course, they had learned little that was new; nevertheless they were a crucial source of information for the younger members.

Engaging imaginatively and creatively affected each participant in some way, be it in terms of their perceptions, understanding, and/or behavior. Importantly, spending more time thinking and writing about the Dearne and other rivers was a trigger for some to try out new actions: one participant reported that she had "walked the riverbanks for the first time"; another reported that he now does "[m]ore walking and encourag[es] family and friends to walk". For some the change was significant and longer-term and was stimulated early on, after the first or second workshop. For others, the change developed more gradually through different stages, affecting initially how the local river and area were perceived and valued, followed by an increased interest in finding out more, and finally initiating behavioral change, such as spending more time in river environments or becoming actively involved in environmental planning and a local NGO.

River basin planning not only requires effective public and stakeholder participation, it also affords invaluable opportunities for social learning. Whilst there are specific opportunities for community involvement in the production of statutory management plans, sustainable development will depend on the processes which follow plan adoption, and so public engagement needs to take a longer term perspective. River restoration is an example of the "future natural" (Adams 2003) whilst we cannot (and should not) attempt to reproduce nature exactly as it was at some arbitrary former time, we are nonetheless involved in exercises to make many stretches of river more naturalistic to promote recovery of ecosystem services. There is some evidence that our work helped create an ambience in which the capacity to do this could be stimulated by mutual communication between the scientists who possess codified knowledge and the local people who possess experience, ideas for change, and wisdom.

\section{CONCLUSION}

Our foray into imaginative engagement has suggested that the approach

- was evaluated as a positive experience by all participants;

- $\quad$ enabled learning about people, rivers, their catchments, and local history;

- raised interest, so that people willingly continued their learning in between events;

- provided an opportunity for the older participants $(60+)$ to contribute historical knowledge;

- triggered some changes to actions by participants in their 30s, 40s, and 50s;

- provided the incentive to search for information about the local river and to think about rivers at different scales; and

- increased the time spent thinking about the state, use, meaning, and management of rivers more generally.

Clearly, this initial exercise was limited in terms of its "reach". However, there is now scope to communicate the written outputs to a wider audience in order to raise interest in and awareness of the future options for the Dearne Valley, and to build on our initial experience.

Imaginative engagement is worthy of further application and investigation within the context of river planning. It also has wider relevance to other environmental issues that involve large-scale and difficult-to-comprehend systemic processes, such as climate change (Buckeley 2000, Few et al. 2007). It would seem to be pertinent to social and institutional learning for sustainable development (Schusler et al. 2003, Tilbury and Wortman 2004) where co-investigation of live issues can be made the subject of shared enquiry and creative involvement. Potentially, therefore, imaginative engagement approaches can complement other participatory methods, and may offer experiences which are enjoyable and rewarding. There is some evidence that capacity to engage in river restoration was increased by building knowledge about historical (and potentially recoverable) attributes, 
strengthening emotional ties to the river, demystifying river basin planning amongst nonprofessionals, and stimulating a deeper awareness of local meanings and appropriate modes of communication amongst scientists. Capacity was also built in terms of the art practice itself-the workshop leader noted marked development of writing skills and responded to requests for individual masterclasses, whilst one participant went on to contribute to a highly regarded local radio program.

The exercise was, inevitably, limited in its outreach and duration. Further work is needed to demonstrate the value of imaginative engagement at a wider scale and to monitor its long-term effect in raising capacity and stimulating change in behavior, understanding, and engagement in the participants and those they affect and reach. Our findings, though, are encouraging and suggest that wider application of the approach would be productive.

Responses to this article can be read online at: http://www.ecologyandsociety.org/vol15/iss3/art18/ responses/

\section{Acknowledgments:}

The authors gratefully acknowledge the funding of the project through the UK Economic and Social Research Council and the Homes and Communities Agency, Targeted Initiative on Skills and Knowledge for Sustainable Communities, award no.

RES-182-25-0006, "Engaging with rivers in a period of uncertainty". We are also grateful for the helpful comments of Nadia Barsoum and Chris Quine of the Forestry Commission, and two anonymous referees. Any errors and omissions remain the authors'own.

\section{LITERATURE CITED}

Adams, W. 2003. Future nature: a vision for conservation. Second edition. Earthscan, London, UK.

Adams, W. M., M.R. Perrow, and A. Carpenter. 2004. Conservatives and champions: river managers and the river restoration discourse in the
United Kingdom. Environment and Planning A 36:1929-1942.

Blackmore, C. 2007. What kinds of knowledge, knowing and learning are required for addressing resource dilemmas?: a theoretical overview. Environmental Science and Policy 10:512-525.

Blackmore, C., R. Ison, and J. Jiggins. 2007. Social learning: an alternative policy instrument for managing in the context of Europe's water. Environmental Science and Policy 10:493-498.

Blake, A., and D. Cloutier-Fisher. 2005. Backyard bounty: exploring the benefits and challenges of backyard garden sharing projects. Local Environment 14:797-807.

Blomqvist, A. 2004. How can stakeholder participation improve European watershed management: the Water Framework Directive, watercourse groups and Swedish contributions to Baltic Sea eutrophication. Water Policy 6:39-52.

Bohensky, E., B. Reyers, and A. S. Van Jaarsveld. 2006. Future ecosystem services in a Southern African river basin. Conservation Biology 20:1051-1061

Buckeley, H. 2000. Common knowledge? Public understanding of climate change in Newcastle, Australia. Public Understanding of Science 9:313-333.

Chartered Institute of Water and Environmental Management. 2009. Arts and the environment: CIWEM's postion on arts and the environment. [online] URL:http://www.ciwem.org/policy-and-in ternational/policy-position-statements/arts-and-theenvironment.aspx.

Collins, K., C. Blackmore, D. Morris, and D. Watson. 2007. A systematic approach to managing multiple perspectives and stakeholding in water catchments: some findings from three UK case studies. Environmental Science and Policy 10:564-574.

Collins, K., R. Ison, and C. Blackmore. 2005. River basin planning project: social learning. Science Report SC050037. Environment Agency, Bristol, UK. [online] URL: http://oro.open.ac.uk/84 45/1/SCHO0805BJHK-e-e.pdf. 
Commission of the European Communities. 2000. Directive of the European Parliament and of the Council establishing a framework for community action in the field of water policy: joint text approved by the Conciliation Committee. 1997/0067(COD) C5-0347/00. Environment Directorate, European Commission, Brussels, Belgium.

Dalrymple, G. 2006. Valuing the water environment: a review of international literature. Scottish Executive Social Research, Scottish Executive Environment and Rural Affairs Department, UK. [online] URL:http://www.scotland. gov.uk/Publications/2006/11/17092457/14.

Department of Environment Food and Rural Affairs. 2006. River basin planning guidance. Defra, London, UK. [online] URL: http://www.def ra.gov.uk/environment/quality/water/wfd/documents/ riverbasinguidance.pdf.

Devon Wildlife Trust. 2005. Dart catchment project: stakeholder and public participation-a project evaluation. Devon Wildlife Trust, Exeter, Devon, UK.

Eden, S. 1998. Environmental issues: knowledge, uncertainty and the environment. Progress in Human Geography 22:425-432.

Eden, S., and S. Tunstall. 2006. Ecological versus social restoration? How urban river restoration challenges but also fails to challenge the sciencepolicy nexus in the United Kingdom. Environment and Planning C: Government and Policy 24:661-680

European Environment Agency. 2005. Climate change and river flooding in Europe. EEA Briefing 2005/01. European Environment Agency, Copenhagen, Denmark.

Few, R., K. Brown, and E. L. Tompkins. 2007. Public participation and climate change adaptation: avoiding the illusion of inclusion. Climate Policy 7:46-59.

Gull, S. E., R. O'Flynn, and J. Y. L. Hunter. 2002. Creative writing workshops for medical education: learning from a pilot study with hospital staff. Medical Humanities 28:102-104.

Hahn, T., P. Olsson, C. Folke, and K. Johansson. 2006. Trust-building, knowledge generation and organizational innovations: the role of a bridging organization for adaptive comanagement of a wetland landscape and Kristiansand, Sweden. Human Ecology 34:573-592.

Ison, R., and D. Watson. 2007. Illuminating the possibilities for social learning in the management of Scotland's water. Ecology and Society 12. [online] URL:http://www.ecologyandsociety.org/vol12/ iss1/art21/.

Jönsson, A., and R. Gustavsson. 2002. Management styles and knowledge cultures, past, present and future, related to multiple-use and urban woodlands. Urban Forestry and Urban Greening 1:39-47.

Junker, B., M. Buchecker, and U. Müller-Böker. 2007. Objectives of public participation: which actors should be involved in the decision making for river restorations? Water Resources Research 43. [online] URL:http://www.agu.org/pubs/crossre f/2007/2006WR005584.shtml.

Kaika, M. 2003. The Water Framework Directive: a new directive for a changing social, political and economic European framework. European Planning Studies 11:299-316

Kemp, P., and J. Griffiths. 1999. Quaking houses: arts, science and the community-a collaborative approach to water pollution. Jon Carpenter Publishing, Oxfordshire, UK.

Kidd, S., and D. Shaw. 2000. The Mersey Basin and its River Valley Initiatives: an appropriate model for the management of rivers? Local Environment 5:191-209.

Ling, C., J. Handley, and J. Rodwell. 2007. Restructuring the post-industrial landscape: a multifunctional approach. Landscape Research 32:285-309.

Marsh, T., and J. Hannaford. 2007. The summer 2007 floods in England and Wales-a hydrological appraisal. Centre for Ecology and Hydrology, Wallingford, UK.

Measham, T.G. 2006. Learning about environments: the significance of primal landscapes. Environmental Management 38:426-434.

Morris, N. J., and S. G. Cant. 2004. The Hebden Bridge Sculpture Trail: can a collaborative and community arts event stimulate new understandings 
of landscape, place and identity? Open Space/ People Space: An International Conference on Inclusive Environments. [online] URL: http://www. openspace.eca.ac.uk/conference/proceedings/PDF/ Morris.pdf.

Moss, T. 2004. The governance of land use in river basins: prospects for overcoming problems of institutional interplay with the EU Water Framework Directive. Land Use Policy 21 (1):85-94.

Moss, T., and J. Monstadt, editors. 2008. Restoring floodplains in Europe: policy contexts and project experiences. International Water Association, London, UK.

Muro, M., and P. Jeffrey. 2008. A critical review of the theory and application of social learning in participatory natural resource management processes. Journal of Environmental Planning and Management 51:325-344.

Murray, L., and K. Myant. 2006. Valuing the water environment: an investigation of environmental attitudes and values to inform implementation of the EC Water Framework Directive. Scottish Executive Social Research, Edinburgh, UK. [online] URL:htt p://www.scotland.gov.uk/Resource/Doc/171705/0047985. pdf.

Newcastle City Council. 2005. URBEM-best practice guidance for citizen involvement in river restoration. Urban River Basin Enhancement Methods, Wallingford, Oxfordshire, UK. [online] URL:http://www.urbem.net/WP9/9.3 citizen invo lvement.pdf.

Orr, P., J. Colvin, and D. King. 2007. Involving stakeholders in integrated river basin planning in England and Wales. Water Resource Management 21:331-349.

Pahl-Wostl, C. 2006. The importance of social learning in restoring the multifunctionality of rivers and floodplains. Ecology and Society 11. [online] URL:http://www.ecologyandsociety.org/vol11/iss1/ art10/.

Pahl-Wostl, C., M. Craps, A. Dewulf, E. Mostert, D. Tabara, and T. Taillieu. 2007. Social learning and water resources management. Ecology and Society 12. [online] URL:http://www.ecologyandso ciety.org/vol12/iss2/art5/.
Pedler, M., N. Spencer, D. Wade, D. Warburton, and D. Wilkinson. 2006. Using science to create a better place\&\#8212improving poor environments 3: the role of learning architectures in developing and spreading good practice. Science Report SC050018/SR3. Environment Agency, Bristol, UK. [online] URL:Www.sharedpractice.org.uk/Downloads/ Learning\%20Architectures\%20Report.pdf.

Pedroli, B. 2005. The nature of lowland rivers: a search for river identity. Pages 259-273 in J. A. Wiens and M. R. Moss, editors. Issues and perspectives in landscape ecology. Cambridge University Press, Cambridge, UK.

Petts, J. 2007. Learning about learning: lessons from public engagement and deliberation on urban river restoration. Geographical Journal 173:300-311.

Piper, J. M. 2005. Partnership and participation in planning and management of river corridors. Planning, Practice and Research 20:1-22.

Pitt, M. 2008. The Pitt Review: lessons learned from the 2007 floods. Cabinet Office, London, UK. [online] URL:http://archive.cabinetoffice.gov.uk/p ittreview/ /media/assets/www.cabinetoffice.gov.uk/ flooding review/pitt review full\%20pdf.pdf.

Rosillon, F. 2004. Valley landscape management: the context of a 'river contract' in the Semois valley, Belgium. Landscape Research 29:413-422.

Sampson, F., editor. 2004. Creative writing in health and social care. Jessica Kingsley, London, UK.

Schusler, T. M., D. J. Decker, and M. J. Pfeffer. 2003. Social learning for collaborative natural resource management. Society and Natural Resources 15:309-326.

Scott J., and G. A Marshall. 2005. Dictionary of sociology. Third edition. Oxford University Press, Oxford, UK.

Seeley Brown, J., S. Denning, K. Groh, and L. Prusak. 2005. Storytelling in organisations. Elsevier Butterworth-Heinemann, Oxford, Oxfordshire, UK.

Simm, J. D., and M. Samuels. 2006. Telling good stories: engaging in dialogue with communities about flood and coastal erosion risk management in a post-modern society. Pages $0 \%$ A2.1-05A2.12 in 
41st Defra flood and coastal management conference, 4-6 July 2006, York, UK. HR Wallingford, Wallingford, Oxfordshire, UK.

Steyaert, P., and J. Jiggins. 2007. Governance of complex environmental situations through social learning: a synthesis of SLIM's lessons for research, policy and practice. Environmental Science \& Policy 10:575-586.

Steyaert, P., and G. Ollivier. 2007. The European Water Framework Directive: how ecological assumptions frame technical and social change. Ecology and Society 12. [online] URL:http://www. ecologyandsociety.org/vol12/iss1/art25/.

Stokman, A. 2008. Water purificative landscapes - constructed ecologies and contemporary urbanism. Pages 51-61 in W. Kuitert, editor. Transforming with water, Proceedings of the 45th world congress of the International Federation of Landscape Architects IFLA 2008, Blauwdruk/ Techne Press, Wageningen, Netherlands.

Tilbury, D., and D. Wortman. 2004. Engaging people in sustainability. The World Conservation Union (IUCN), Gland, Switzerland.

Tippett, J. 2005. “Think like an ecosystem"embedding a living system paradigm into participatory planning. Systemic Practice and Action Research 17::603-622.

Walker, G. B., S. L. Senecah, and S. E. Daniels. 2006. From the forest to the river: citizens' views of stakeholder engagement. Human Ecology Review 13:193-202.

White, I., and J. Howe. 2003. Planning and the European Union Water Framework Directive. Journal of Environmental Planing and Management 46:621-631.

Wilkinson, D. 2005. Joining up: Stockbridge pathfinder. Science Summary SCO0805BJMK-EP. Science Report SC010044/SR4. Environment Agency, UK. [online] URL:http://sharedpractice.org. uk/Downloads/Stockbridge Pathfinder Report.pdf.

Zedler, J., and S. Kercher. 2005. Wetland resources: status, trends, ecosystem services, and restorability. Annual Review of Environment and Resources 30:39-74. 